\title{
Reproductive cycle and gonad development of the Northern Argentinean Mesodesma mactroides (Bivalvia: Mesodesmatidae)
}

\author{
Marko Herrmann · José E. F. Alfaya • \\ Mauro L. Lepore · Pablo E. Penchaszadeh • \\ Jürgen Laudien
}

Received: 3 June 2008/Accepted: 17 February 2009/Published online: 10 March 2009

(C) Springer-Verlag and AWI 2009

\begin{abstract}
The reproductive cycle and gonad development of the yellow clam Mesodesma mactroides was studied over a period of 24 months (January 2005-December 2006) at the Argentinean sandy beach Santa Teresita. Histological examination of gonadal tissue revealed that sex ratios did not significantly deviate from the proportion of $1: 1$ and no case of hermaphroditism was found. The reproductive cycle of M. mactroides followed an annual cyclicality, which was significantly correlated to monthly mean sea surface temperatures (SST). Oocytes showed highest abundance in winter, indicating a process of gonadal development and sexual maturation. The mean oocyte size decreased significantly during spring. Modal oocyte sizes decreased significantly during winter and late spring of each year, suggesting spawning events. The condition index was not useful in describing the annual reproductive cycle of M. mactroides. Ash-free, shell-free dry mass was chosen to detect the condition of the specimens, and this significantly correlated with monthly mean SST and the gametogenic cycle. Annual recruitment patterns during summer-autumn indicated a 3-month-long planktonic phase of M. mactroides. The reproduction cycle and gonad development of
\end{abstract}

M. Herrmann and José E. F. Alfaya contributed equally to this work.

Communicated by H.-D. Franke.

M. Herrmann $(\varangle) \cdot J$. Laudien

Alfred Wegener Institute for Polar and Marine Research, P.O. Box 120161, 27515 Bremerhaven, Germany

e-mail: marko.herrmann@gmx.de

M. Herrmann · J. E. F. Alfaya · M. L. Lepore ·

P. E. Penchaszadeh

Museo Argentino de Ciencias Naturales 'Bernardino Rivadavia', Av. Ángel Gallardo 470, 3er piso lab. 57, C1405DJR Buenos Aires, Argentina
M. mactroides showed only weak differences between data from the present study and those collected 40 years ago.

Keywords Yellow clam · Histology · Condition index · Ash-free, shell-free dry mass · Oocyte size and abundance

\section{Introduction}

The yellow clam Mesodesma mactroides ${ }^{1}$ Reeve, ${ }^{2} 1854$ (Bivalvia: Mesodesmatidae), locally called 'almeja amarilla', was historically the most common bivalve in its geographic distribution (Parodiz 1942; Stuardo 1964; Defeo 1989). However, recently, its abundance has significantly decreased (Lima et al. 2000; Bergonci and Thomé 2008; Herrmann 2009). The suspension-feeder currently inhabits intertidal Atlantic sandy beaches from tropical $\left(23^{\circ} \mathrm{S}\right.$ Ilha Grande, Rio de Janeiro State, Brazil) to temperate regions $\left(40^{\circ} \mathrm{S}\right.$ Isla del Jabalí, Province of Buenos Aires, Argentina; Rios 1994; Fiori and Morsán 2004). Thus, its distributional range covers about $1,800 \mathrm{~km}$ of South Brazilian sandy beaches, $22 \mathrm{~km}$ in Uruguay, and $375 \mathrm{~km}$ in Argentina, where it represents the only Mesodesma species occurring throughout the mediolitoral (Olivier et al. 1971). On the beaches of northern Argentina,

\footnotetext{
${ }^{1}$ M. mactroides reference specimens were deposited in the collections of the 'Museum für Naturkunde der Humboldt-Universität zu Berlin' and the 'Museo Argentino de Ciencias Naturales-Bernardino Rivadavia' under the reference numbers ZMB/Moll.104643 and MACN-In37513, respectively.

2 In previous studies, Deshayes 1854 was cited falsely as the author who first described M. mactroides. However, this description was not published by Deshayes but by his colleague Reeve; thus, the corresponding author of M. mactroides is Reeve (see Reeve 1854; Deshayes 1855).
} 
it is found together with the sympatric and dominant surf clam Donax hanleyanus (Olivier et al. 1971; Penchaszadeh and Olivier 1975; Herrmann 2009). During the 1940s and 1950s, M. mactroides was an important economic resource for Argentina, with a maximum exploitation rate of 1,079 tonnes in 1953. As a consequence of overfishing, the clam fishery was closed in 1956 (Coscarón 1959). Argentinean M. mactroides populations never recuperated and in the 1990s and recently populations were further depleted by mass mortality events. Although red tides and high heavy metal concentrations were given as possible reasons for the massive decimation, the actual cause was never found (Odebrecht et al. 1995; Fiori and Cazzaniga 1999; Thompson and Sánchez de Bock 2007). Various authors have suggested illegal extractions and the impact of tourist activities as probable main factors for the failure of stock recovery (Bastida et al. 1991; Bastida et al. 1996; Herrmann 2009).

Aspects of population dynamics for $M$. mactroides such as recruitment, growth, production, and mortality are very well studied for the Argentinean (Bastida et al. 1996; Fiori and Cazzaniga 2002; Fiori et al. 2004; Fiori and Morsán 2004; Fiori and Defeo 2006; Herrmann 2009), the Uruguayan (Defeo et al. 1986, 1988, 1991, 1992; Defeo 1989; Brazeiro and Defeo 1999; Lima et al. 2000), and the Brazilian coasts (Narchi 1981; Gil and Thomé 2000; Bergonci and Thomé 2008). However, with the exception of Christiansen (1971), we know of no further studies dealing with the reproductive cycle of this species.

The present study aims to describe the reproductive cycle and gonad development of the yellow clam population of the northern Argentinean sandy beach Santa Teresita in comparison with the above-mentioned study, which was carried out 40 years ago.

\section{Materials and methods}

\section{Study area}

The present study was carried out at the three south Atlantic sandy beaches Santa Teresita $\left(36^{\circ} 32^{\prime} \mathrm{S}, 56^{\circ} 41^{\prime} \mathrm{W}\right)$, Mar de las Pampas $\left(37^{\circ} 19^{\prime} \mathrm{S}, 57^{\circ} 00^{\prime} \mathrm{W}\right)$, and Faro Querandí $\left(37^{\circ} 29^{\prime} \mathrm{S}, 57^{\circ} 07^{\prime} \mathrm{W}\right.$; Fig. 1), whereby we want to highlight that $M$. mactroides was only abundant at the first mentioned location during the entire sampling period. Therefore, the reproductive cycle and gonad development of the intertidal yellow clam was studied during alternate spring tides only from the sandy beach Santa Teresita. According to McLachlan's (1980) rating scale for exposure and Short and Wright's (1983) classifications of beach types, Santa Teresita can be characterised as sheltered and dissipative (for detailed parameters see: Herrmann 2009).
This is an open ocean beach receiving continuous wave action and is subject to semidiurnal tides, with a maximum tide range of $1.6 \mathrm{~m}$; spring tides average $1.7 \mathrm{~m}$ and mean neap tides $0.2 \mathrm{~m}$. The sea surface temperature (SST) varies between $11^{\circ} \mathrm{C}$ in winter and $23^{\circ} \mathrm{C}$ in summer. The study site is composed of good-moderate fine sand, with a mean particle diameter of 2.26 phi (Herrmann 2009). The sandy beach of Santa Teresita is affected by a freshwater seepage and a southward current that brings water masses from the $290 \mathrm{~km}$ long and up to $220 \mathrm{~km}$ wide estuary of the Río de la Plata and is thus characterized by a mean salinity of 31 . This beach is well drained and oxygenated.

\section{Sampling and histological examination}

Samples of $M$. mactroides were collected monthly between January 2005 and December 2006 at a series of stations ( $4 \mathrm{~m}$ intervals). The stations were positioned along three transects separated by $20 \mathrm{~m}$ intervals and located perpendicular to the shoreline from the spring tide high water mark to the neap tide low water mark. At each station, three replicated sand samples were excavated to $35 \mathrm{~cm}$ depth using a $0.16 \mathrm{~m}^{2}$ steel corer, and thereafter sieved individually on a $1 \mathrm{~mm}$ mesh. For biomass determinations as well as for calculations of the condition index (CI), a total of 720 sampled specimens were preserved in $70 \%$ ethanol and subsequently analysed in the laboratory, as described in the following paragraph. For histological examinations, again, a total of 720 individuals were sampled and gonads, covering the full range of sizes of specimens under gametogenic activity (2-64 $\mathrm{mm}$ anteriorposterior shell length [apSL]), were selected for histological analysis. The apSL of clams was measured in situ to the nearest $0.01 \mathrm{~mm}$ with a digital vernier calliper (Mitutoyo, model 500-161). For histological processing, intact clams with cut through adductor muscles were fixed in Bouin's solution for two hrs, afterwards transferred into a $70 \%$ ethanol solution and later processed in the laboratory using standard methods (Romeis 1989), including embedding in paraffin, sectioning at $5 \mu \mathrm{m}$ and staining with hematoxylin-eosin. Photographical analyses were carried out with a Zeiss Axio Imager Z1 light microscope equipped with a Sound Vision digital camera using the imaging software AxioVision 4.4 (2008). Abundance $\left(\mathrm{mm}^{-2}\right)$ and size of oocytes (mean diameter obtained from measurements of 30 oocytes per specimen) were determined from histological slides, except for the period of January to February 2005 and January 2006, where clams showed only the gonad stage 0 (sexual rest stage with apSL $<10 \mathrm{~mm}$ ). Gonads of $M$. mactroides were classified into five developmental stages following Christiansen (1971), but combining the early active with the late active stage and the early ripe with the ripe stage (Fig. 2, 
Fig. 1 Map of the study sites Santa Teresita $(S)$, Mar de las Pampas $(M)$ and Faro Querandí $(F), M$. mactroides was only abundant at the first mentioned location during the entire sampling period (black ladled). Filled circle indicates the southern-most distribution limit of $M$. mactroides at Isla del Jabalí. Dotted areas present northern and southern sandy beaches of the Province of Buenos Aires where major $M$. mactroides populations existed in 1959 (Coscarón)

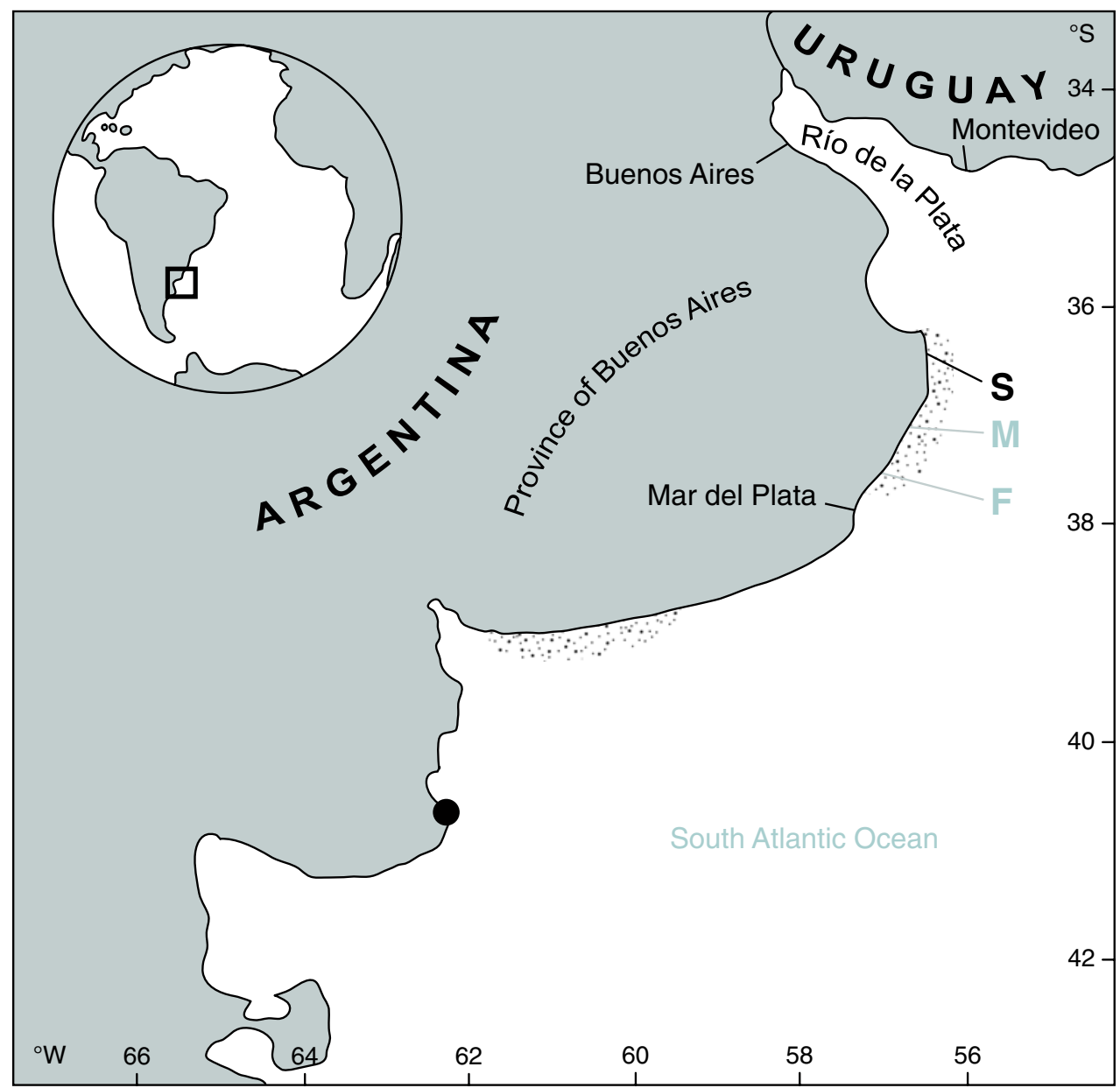

As shown below, the CI was not the best proxy to

Table 1). Individuals without germ cells were categorized in the sexual rest stage. Using chi-square $\left(\chi^{2}\right)$ analysis, the sex ratio of $M$. mactroides was calculated according to the presence of oocytes and sperms. As clams were in a resting stage between January and March of both years, the respective sex ratio could not be determined. The SST was measured daily at 13:00 pm using a digital thermometer to a precision of $0.1{ }^{\circ} \mathrm{C}$. Data of length-frequency distributions of $M$. mactroides and their consequent cohort analyses were taken from Herrmann (2009).

\section{Condition index, biomass and recruitment}

The CI of preserved M. mactroides was calculated to trace seasonal variation in the visceral mass. After blotting on filter paper, the total wet mass was recorded immediately to the nearest $0.1 \mathrm{mg}$. After this, valves, mantle, siphons, retractor and adductor muscles were removed. The wet mass of the resulting standard compact unit consisting of the visceral mass and foot was recorded. The CI was calculated according to the equation of de Villiers (1975), namely CI $=100 M_{\mathrm{v}} /\left(M_{\mathrm{t}}-M_{\mathrm{v}}\right)$, where $M_{\mathrm{v}}$ is the wet visceral mass (including the foot) and $M_{\mathrm{t}}$ is the total wet mass. evaluate the condition of the individuals, since the gonadfoot unit could not separated very accurately. Therefore, ash-free, shell-free dry mass (AFDM) of preserved yellow clams was recorded throughout the sampling time as an estimator of specimens' condition, whereby the conversion factor of 0.186 was empirically determined according to Brey et al. (1988).

Recruits, here defined as clams ranging from 2 to $6 \mathrm{~mm}$ apSL, were sampled and measured as described in the previous chapter.

\section{Statistical analysis}

Sex ratios (male:female) of yellow clams were calculated according to the presence of oocytes and spermatozoa using $\chi^{2}$ analysis. The influence of SST on the gametogenic cycle, as well as its correlation with $\mathrm{CI}$ and AFDM were statistically analyzed by Spearman's rank order correlation. Furthermore, to evaluate the null hypothesis of no difference in the gametogenic cycle throughout the year, one-way analysis of variance (ANOVA) was preformed with subsequent Tukey HSD post hoc test when differences 
Fig. 2 Microphotography (colour pictures of full size: Herrmann et al. 2008) of male gonad stages of $M$. mactroides: a early active stage, $\mathbf{b}$ late active stage, c early ripe stage, d, e ripe stage, $\mathbf{f}$ partially spawned stage, $\mathbf{g}$ spent stage, h recovery stage ( $a w$ alveolar wall, gn goias, $s$ sperm, $s d$ spermatids, $t f$ transverse fibre, scale bars are $100 \mu \mathrm{m}$ )

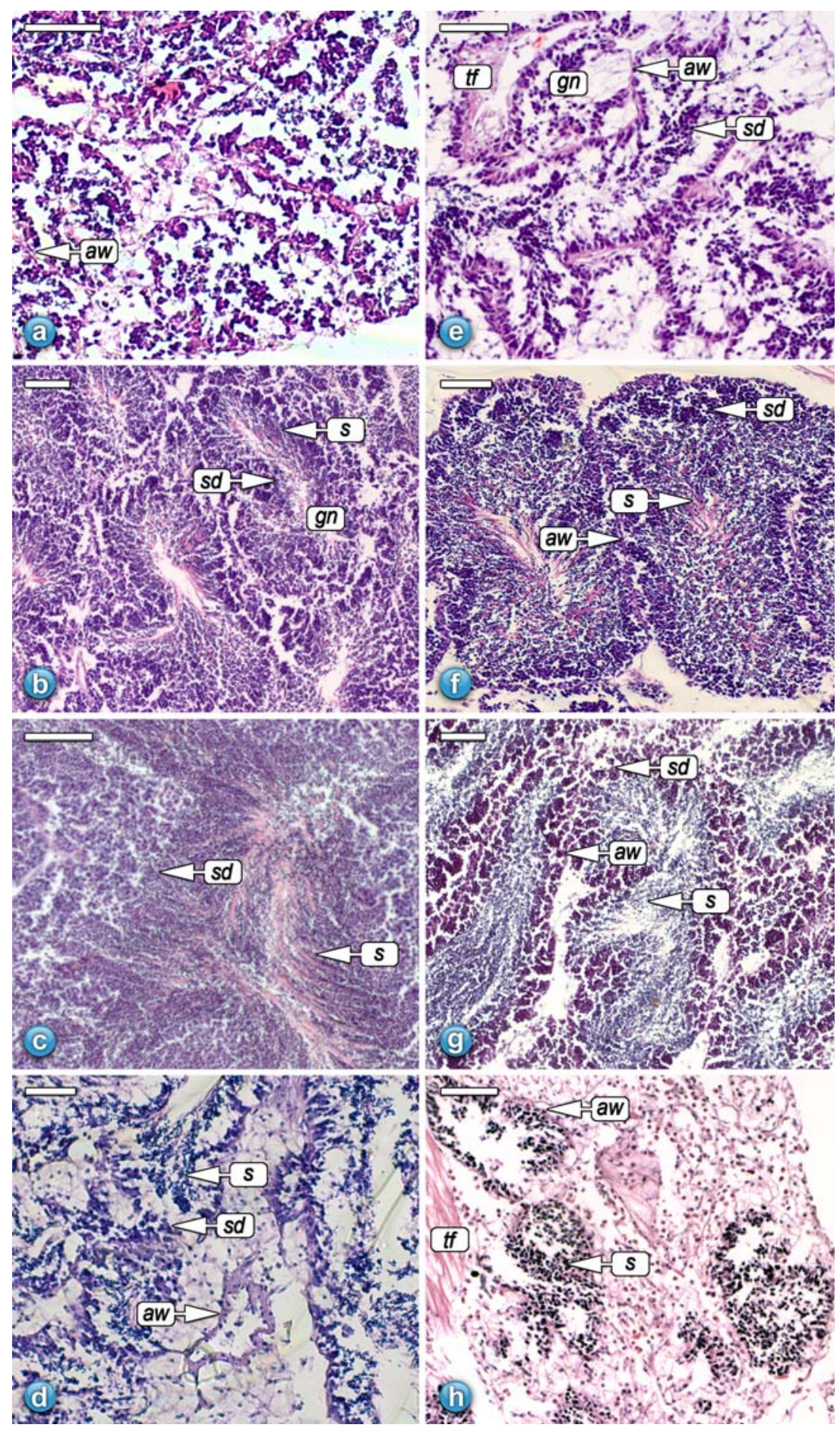

were found, using months or seasons as factor and proportion of ripe and spawning individuals as dependent variable. Temporal differences of oocyte abundance were tested by one-way ANOVA. All statistical analyses were carried out using the statistical package SPSS version 17.0 (SPSS 2008). Differences were considered significant at a level of $\alpha=5 \%$ (Zar 1999).

\section{Results}

Gonad development

Histological examinations of the gonads from the 24 month sampling series demonstrated that the reproductive cycle of $M$. mactroides has a distinct seasonality. 
Table 1 Explanation of the gametogenic scale and the use of descriptive terms (primer column: present study; second column: after Christiansen 1971), utilized in scoring histological analysis of gonad tissue to assess the gametogenic stages of M. mactroides

\begin{tabular}{|c|c|c|c|c|}
\hline \multicolumn{3}{|l|}{ Gonad stages } & \multirow[t]{2}{*}{ Brief description of gonad } & \multirow[t]{2}{*}{ *Photo } \\
\hline Present study & \multicolumn{2}{|c|}{ After Christiansen (1971) } & & \\
\hline Sexual rest & 0 & Sexual rest & $\begin{array}{l}\text { A total absence of gametes, making it impossible to distinguish } \\
\text { between sexes, empty follicles are observed }\end{array}$ & \\
\hline \multirow[t]{2}{*}{ Active } & I & Early active stage & $\begin{array}{l}\text { Follicles few and small, sex distinguishable, protogonia and gonia in } \\
\text { mitosis }\end{array}$ & a \\
\hline & II & Late active stage & $\begin{array}{l}\text { Follicle size increases, spermatogonia and spermatocytes in males, } \\
\text { oogonia and previtellogenic oocytes in females }\end{array}$ & $\mathrm{b}$ \\
\hline \multirow[t]{2}{*}{ Ripe } & III & Early ripe stage & $\begin{array}{l}\text { Follicle size increases and occupies the entire tissue, germinal cells in } \\
\text { all phases of gametogenesis }\end{array}$ & $\mathrm{c}$ \\
\hline & IV & Ripe stage & $\begin{array}{l}\text { Polygonal follicles almost full of ripe gametes, spermatozoa occupy } \\
\text { most of follicle, free ripe polygonal oocytes in the lumen }\end{array}$ & $\mathrm{d}$ and $\mathrm{e}$ \\
\hline \multirow[t]{2}{*}{ Spawning } & $\mathrm{V}$ & Partially spawned stage & $\begin{array}{l}\text { Gonoducts with mature gametes in emission. Spermatozoa lose radial } \\
\text { disposition. Free ripe rounded oocytes in the lumen and empty } \\
\text { spaces }\end{array}$ & $\mathrm{f}$ \\
\hline & VI & Spent stage & Follicles small and practically empty, residual gametes degrading & g \\
\hline Cytolysed & VII & Recovery stage & $\begin{array}{l}\text { Gonadal follicles at this stage are empty, except for residual gametes, } \\
\text { amoebocytes are present within the follicles, close to the walls and } \\
\text { in the centre }\end{array}$ & $\mathrm{h}$ \\
\hline
\end{tabular}

The individual stages of male and female yellow clam gonads are imaged at Figs. 2 and 3, respectively (*Photo)

The sex ratio did not deviate significantly from the proportion of $1: 1\left(\chi^{2}=1.711, d f=1, p>0.05\right)$ during the study period. About $42 \%(N=302)$ of the individuals were identified as females, $38 \%(N=274)$ as males, and $20 \%(N=144)$ were in a sexual rest stage, which occurs mainly in summer. No case of hermaphroditism was found. Male (Fig. 2a, b) and female (Fig. 3a, b) gonads were active from austral autumn-spring with maximum values in winter and in the ripe stage (male: Fig. 2c-e, female: Fig. 3c-e) during the same period (Fig. 4a, b). Spawning of males (Fig. 2f, g) took place mainly in winter-spring (from July to November 2005 and from August to December 2006; Fig. 4a). Females spawned (Fig. 3f, g) between October and November (2005) and June, and November and December (2006) (Fig. 4b). Male gonads were cytolysed (Fig. 2h) during winter and spring (Fig. 4a), whereas cytolysed stages of females (Fig. 3h) were present between autumn and winter (in June, July) and in late spring (November to December 2005 and December 2006; Fig. 4b).

\section{Reproduction cycle}

The examination of histological sections confirmed a seasonal gonadal development in $M$. mactroides. SST (Fig. 5a) was significantly correlated twice with the gametogenic cycle (gonad stages ripe and spawning, Fig. 5b); between February and March of both years (Spearman's rank order correlation, $r_{\mathrm{s}}=-0.833, p<0.05$,
$N=8$ ) and between July and October of both years (Spearman's rank order correlation, $r_{\mathrm{s}}=0.850, p<0.05$, $N=8$ ). Furthermore, the relative proportion of ripe and spawning individuals was significantly different between months $\left(F_{11,12}=7.623, p<0.05\right)$ and seasons $\left(F_{3,20}=\right.$ $7.305, p<0.05)$, whereas the proportion of ripe and spawning female individuals was significantly higher in spring and autumn (Tukey HSD post hoc test; Fig. 5b).

In both years, yellow clam oocytes showed highest abundance in winter with a maximum in September (oneway ANOVA, August to October vs. remaining year, $F_{1,15}=6.594, p<0.05$; Fig. $5 \mathrm{c}$ ), indicating a seasonal process of gonadal development and sexual maturation. Minimum oocyte abundance was observed in autumnwinter and in late spring of both years (one-way ANOVA, May to July and December vs. rest of the year, $F_{1,15}=4.847, p<0.05$; Fig. 5 c), where most of the clams were in the cytolysed stage (Fig. 4).

Mean oocyte size decreased significantly in spring of both years (one-way ANOVA, October-December vs. April-September, $F_{1,15}=4.692, p<0.05$ ) (Table 2).

Unimodal histograms of monthly oocyte size classes ranged from $5 \mu \mathrm{m}$ in November-December to $60 \mu \mathrm{m}$ in August-September (Fig. 6). Modal oocyte sizes decreased significantly twice each year in winter and late spring, suggesting two spawning events (one-way ANOVA testing August and December vs. the other months, $F_{1,12}=35.368, p<0.05$; see dotted arrows in Fig. 6). 
Fig. 3 Microphotography (colour pictures of full size: Herrmann et al. 2008) of female gonad stages of $M$. mactroides: a early active stage, $\mathbf{b}$ late active stage, $\mathbf{c}$ early ripe stage, d, e ripe stage, $\mathbf{f}$ partially spawned stage, $\mathbf{g}$ spent stage, h recovery stage (aw alveolar wall, $g n$ goias, $o$ oocyte, $t f$ transverse fibre, scale bars are $100 \mu \mathrm{m})$
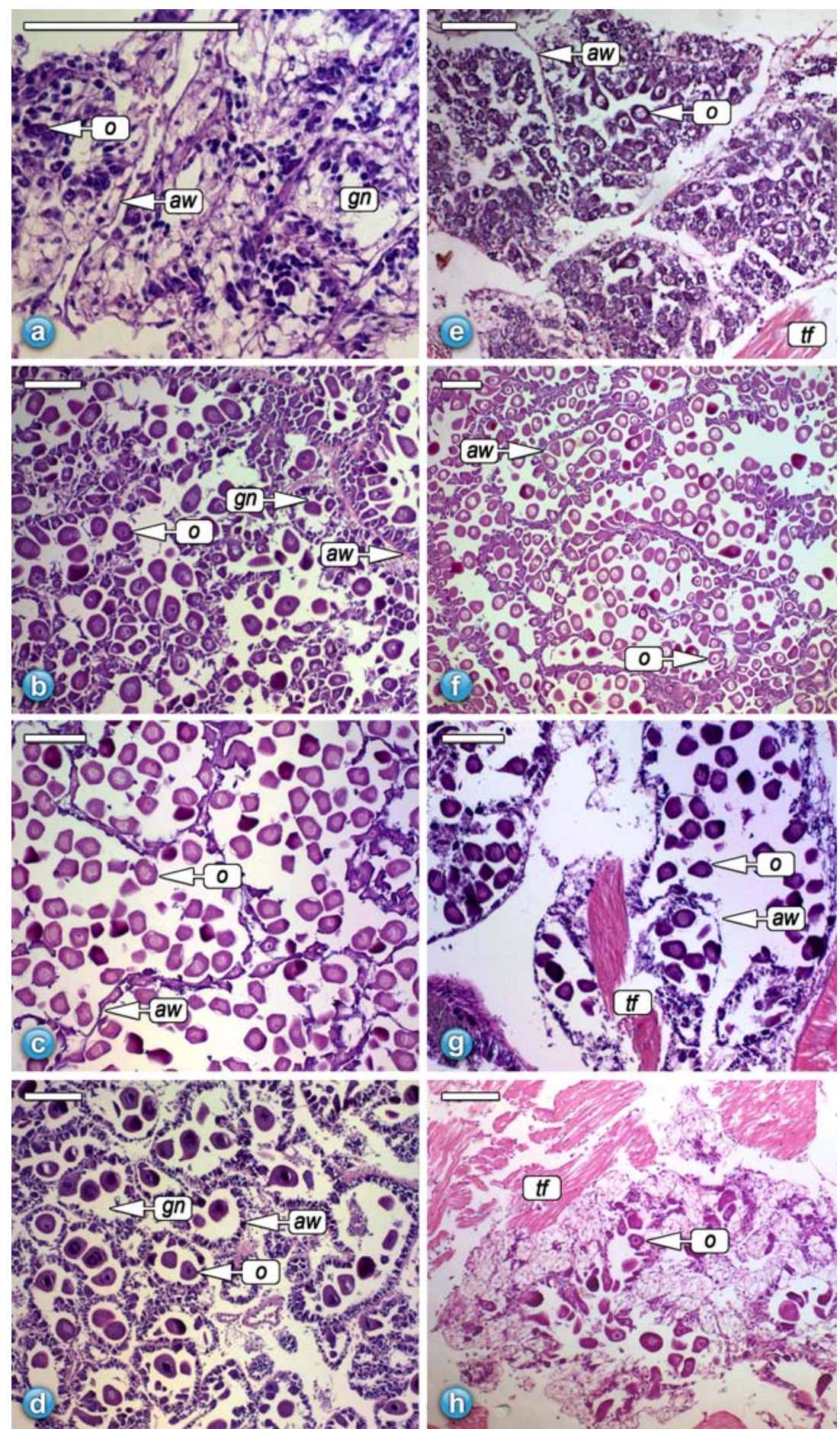

Condition index, biomass, and recruitment

Although the annual reproductive cycle of $M$. mactroides did not significantly correlate with the CI (Spearman's rank order correlation, $p>0.05$ ), specimens showing periods of ripeness and spawning demonstrated an increasing trend of $\mathrm{CI}$ in autumn-winter, and specimens showing periods of cytolysed and active stages demonstrated a decreasing trend of CI in spring-summer of both years, respectively (Fig. 5b, d).

The seasonal variation of the yellow clams' biomass (AFDM) was significantly correlated with SST during winter and spring (July-December) of both years (Spearman's rank correlation, $r_{\mathrm{s}}=0.789, p<0.05, N=12$ ), an 
Austral seasons

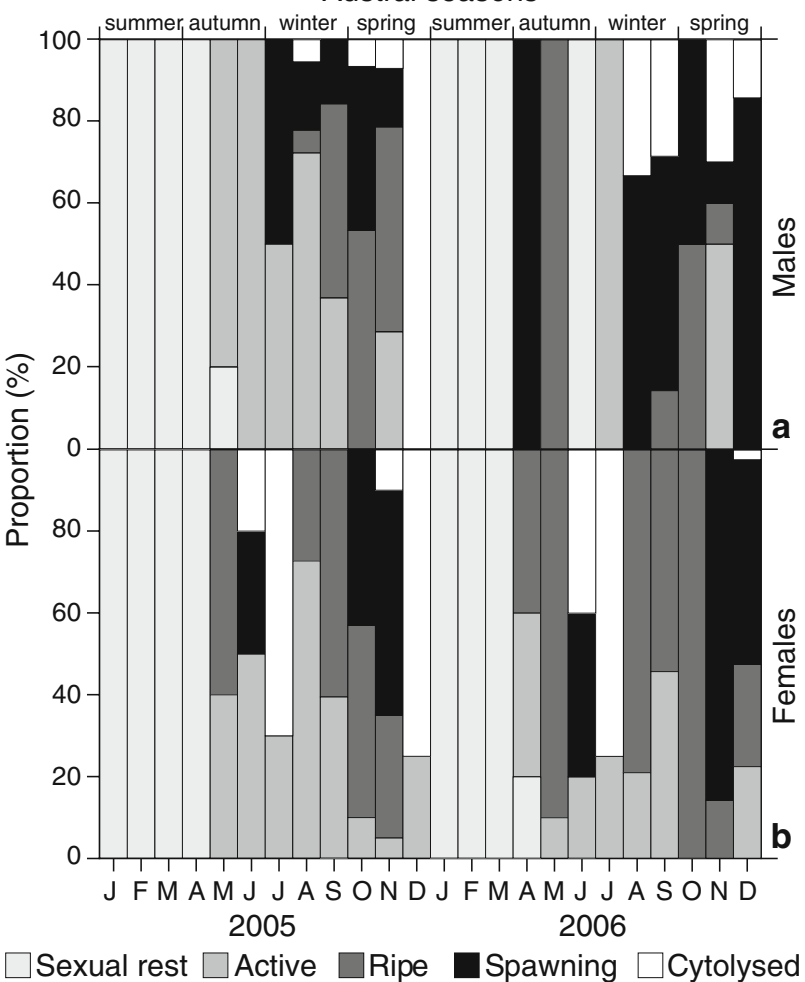

Fig. 4 Proportion of distinct gonad stages in mature male (a) and female (b) M. mactroides, sampled at Santa Teresita

increase of AFDM occurred alongside higher SST (Fig. 5a, e). Values of AFDM were also significantly correlated with mature gonad stages (ripe and spawning) during winter and spring (July-November) of 2005 and 2006 (Spearman's rank correlation, $\left.r_{\mathrm{s}}=0.721, p<0.05, N=10\right)$. The AFDM increased concurrently with the maturation of the gonad (Fig. 5c, e). In the second year, higher values of AFDM indicated growth and gonad development in the same cohort analyzed already in the previous year.

Recruits of the yellow clam settled on the Santa Teresita sandy beach in both years during summer and autumn (in 2005: January-July; in 2006: February-May; Fig. 5f). Thus, the settling period of recruits is again significantly correlated with SST: abundance of recruits increased significantly during summer-autumn in both years (Spearman's rank order correlation, $r_{\mathrm{s}}=0.421, p<0.05$, $N=24 ;$ Fig. 5a, f).

\section{Discussion}

\section{Gonadal development}

The reproductive strategy of $M$. mactroides from Santa Teresita (present study) is summarized in Table 3 and

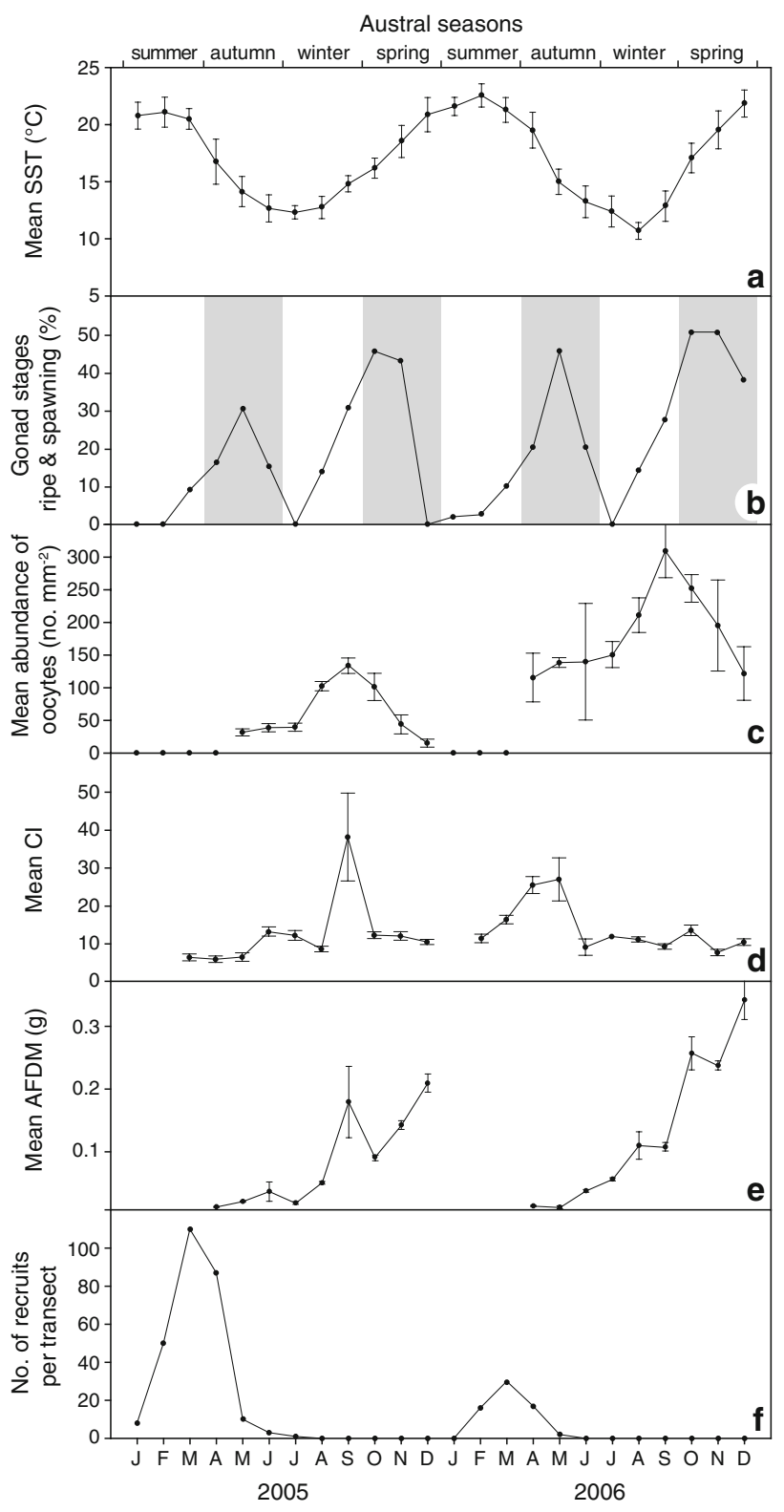

Fig. 5 M. mactroides at Santa Teresita: a mean SST measured daily at Santa Teresita, b percentage of gonad stages ripe and spawning, c mean abundance of oocytes (no. $\mathrm{mm}^{-2}$ ), $\mathbf{d}$ mean condition index (CI), e mean biomass (AFDM) (g) and $\mathbf{f}$ number of recruits $(2-6 \mathrm{~mm}$ apSL) recorded per monthly transect. Grey areas indicate seasons where Carreto et al. (1995) observed chlorophyll $a$ maxima with main peaks during spring and secondary peaks during autumn in the Buenos Aires shelf region. Error bars standard deviation. Data sets of graphics are published in Herrmann et al. (2008)

compared with the 40-year-old historical data obtained from a Mesodesma-population approximately $100 \mathrm{~km}$ south of the Santa Teresita population (Mar Azul, Christiansen 1971). Table 3 shows a clear difference between the gonad stages during summer. Whereas Christiansen (1971) found nearly all developmental stages all year round, in the 
Table 2 M. mactroides. Monthly SST $\left({ }^{\circ} \mathrm{C}\right)$, values of oocyte size $(\mu \mathrm{m})$, mean oocyte size $(\bar{x})$, number of females $(f)$, number of measured oocytes $(o)$, and stages of oocyte development (according to Table 1$)$

\begin{tabular}{|c|c|c|c|c|c|c|c|}
\hline Year & Month & $\operatorname{SST}\left({ }^{\circ} \mathrm{C}\right)$ & Oocyte size $(\mu \mathrm{m})$ & $\bar{x} \pm \mathrm{SD}(\mu \mathrm{m})$ & $f$ & $o$ & Stage of development \\
\hline \multirow[t]{12}{*}{2005} & Jan & 21 & - & - & - & - & Sexual rest \\
\hline & Feb & 21 & - & - & - & - & Sexual rest \\
\hline & Mar & 20 & - & - & - & - & Sexual rest \\
\hline & Apr & 17 & - & - & - & - & Sexual rest \\
\hline & May & 14 & $29-30$ & $29.00 \pm 1.06$ & 3 & 60 & Ripe \\
\hline & Jun & 13 & $23-49$ & $27.83 \pm 1.19$ & 3 & 30 & Active \\
\hline & Jul & 12 & $12-43$ & $36.80 \pm 1.03$ & 3 & 90 & Cytolysed \\
\hline & Aug & 13 & $10-53$ & $26.85 \pm 0.55$ & 17 & 289 & Active \\
\hline & Sep & 15 & $15-48$ & $32.43 \pm 1.36$ & 11 & 316 & Active and spawning \\
\hline & Oct & 16 & $18-45$ & $31.30 \pm 1.27$ & 6 & 208 & Ripe \\
\hline & Nov & 19 & $8-58$ & $30.95 \pm 2.16$ & 10 & 273 & Spawning \\
\hline & Dec & 21 & $8-47$ & $16.01 \pm 1.56$ & 3 & 25 & Cytolysed \\
\hline \multirow[t]{12}{*}{2006} & Jan & 22 & - & - & - & - & Sexual rest \\
\hline & Feb & 23 & - & - & - & - & Sexual rest \\
\hline & Mar & 21 & - & - & - & - & Sexual rest \\
\hline & Apr & 20 & $16-44$ & $33.17 \pm 4.27$ & 3 & 54 & Active and ripe \\
\hline & May & 15 & $23-45$ & $34.66 \pm 0.90$ & 3 & 28 & Ripe \\
\hline & Jun & 13 & $13-43$ & $33.16 \pm 2.08$ & 3 & 90 & Spawning and cytolysed \\
\hline & Jul & 12 & $13-45$ & $36.01 \pm 2.02$ & 3 & 60 & Cytolysed \\
\hline & Aug & 11 & $10-53$ & $25.70 \pm 2.71$ & 10 & 286 & Ripe \\
\hline & Sep & 13 & $10-55$ & $30.53 \pm 2.80$ & 10 & 325 & Ripe \\
\hline & Oct & 17 & $13-59$ & $33.61 \pm 0.87$ & 13 & 454 & Ripe \\
\hline & Nov & 20 & $8-45$ & $24.21 \pm 2.95$ & 5 & 208 & Spawning \\
\hline & Dec & 22 & $13-51$ & $32.37 \pm 2.43$ & 7 & 195 & Spawning \\
\hline
\end{tabular}

present study, the active, ripe, spawning, and cytolysed stages were only recorded from autumn to spring and the sexual rest stage occurred only in summer. The existence of a sexual rest period has also been described for other bivalves (Donax serra: Laudien et al. 2001; Ensis siliqua and E. arcuatus: Darriba et al. 2004, 2005). The absence of active gonad stages in both summers studied is attributed to a single cohort with a small shell length (mean apSL of $8 \mathrm{~mm}$ in summer seasons: Herrmann 2009) and to the consequent immaturity (sexual rest stage) of $\mathrm{M}$. $\mathrm{mac}$ troides during this period. In contrast to the recent population structure of the yellow clam, Olivier and Penchaszadeh (1971) found three cohorts where individuals of commercial size (>60 mm, Coscarón 1959) were found throughout the year. However, comparison of data from areas with different beach morphodynamics (Santa Teresita: dissipative and sheltered; Mar Azul: exposed and intermediate) is difficult; Delgado and Defeo (2007) found differential behavior patterns in the reproductive strategy of D. hanleyanus when comparing reflective and dissipative beaches.
Reproduction cycle

The present investigation of $M$. mactroides gonads suggests two reproductive events per year; the first one in winter and the second one in spring. Christiansen (1971) also recorded two spawning events for the same species at the same beach; however, these occurred later in the season (spring and early summer). For the congener M. donacium, two spawning events were also observed by Filun Villablanca (1992) in northern Chile where reproductive events occurred in spring-summer and autumn. However, Peredo et al. (1986) observed only one spawning period for $M$. donacium from the southern Chilean coast. These differences may be attributed to distinct environmental conditions such as SST, salinity, and food availability (Sastry 1970; de Villiers 1975; Peredo et al. 1986; Penchaszadeh et al. 2000; Kraeuter and Castagna 2001; Laudien et al. 2001). Seasonal changes in SST trigger gametogenesis, and further to this, short-term temperature changes may stimulate spawning (Ansell 1961; Seed 1976). The present results show that changes in SST are 


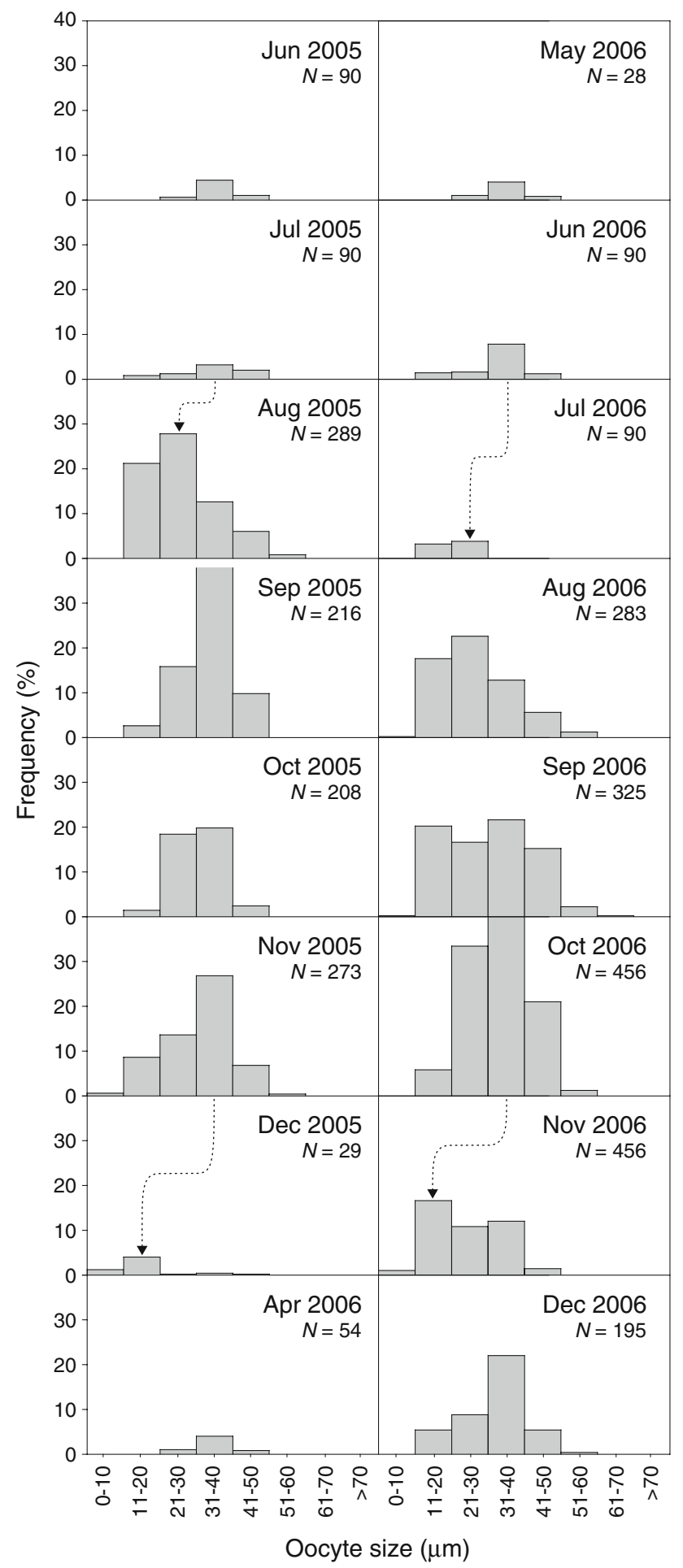

Fig. 6 Monthly oocyte size-frequency distribution of M. mactroides collected at Santa Teresita. The abrupt decreases of oocyte modal sizes in August/December 2005 and in July/December 2006 indicate two spawning events per year (dotted arrows). $N$ number of oocytes

significantly correlated with gonad development. Low mean temperatures coincided with maximum oocyte size and gamete initiation (late Fall-winter). Increases in SST
Table 3 Reproductive strategy of $M$. mactroides comparing data from present study with data four decades ago (Christiansen 1971)

\begin{tabular}{llllll}
\hline & $\begin{array}{l}\text { Gonad } \\
\text { stages }\end{array}$ & Summer & Autumn & Winter & Spring \\
\hline Present study & Active & & $\times$ & $\times$ & $\times$ \\
& Ripe & & $\times$ & $\times$ & $\times$ \\
& Spawning & $\times$ & $\times$ & $\times$ \\
& Cytolysed & $\times$ & $\times$ & $\times$ \\
Christiansen (1971) & Active & $\times$ & $\times$ & $\times$ & $\times$ \\
& Ripe & $\times$ & $\times$ & $\times$ & $\times$ \\
& Spawning & $\times$ & $\times$ & $\times$ & $\times$ \\
& Cytolysed & $\times$ & $\times$ & & $\times$ \\
\hline
\end{tabular}

throughout winter periods of both years matched well with the growth of gametes (mean oocyte size: $5 \mu \mathrm{m}$ in July to $41 \mu \mathrm{m}$ in September 2005 and $4 \mu \mathrm{m}$ in July to $48 \mu \mathrm{m}$ in September 2006) and an increase in the number of individuals in ripe and spawning stages (Fig. 5a, b). Maximum gamete ripeness and size observed in winter (July-August) was related to seasonal minimum SST. Noticeable decreases in oocyte sizes (Fig. 6), abundance, and the increased number of spawned and spent individuals was associated with rapid increases in SST during spring (Fig. 5a). Multiple stages of gonad conditions were also observed in late spring (November). However, several authors (e.g. Sastry 1968; Giese 1974; Sastry 1979) have mentioned that the reproductive cycle of suspension feeders is not only influenced by physical parameters such as SST, but also by changes in phytoplankton biomass and species compositions. The increase of chlorophyll $a$ concentrations in the Buenos Aires shelf region observed during winter and summer by Carreto et al. (1995) with a main peak in spring and a secondary peak in autumn, correspond considerably with the dominance of $\mathrm{M}$. mactroides in ripe and spawning stages (Fig. 5b). This suggests that phytoplankton may also have a direct impact on the reproductive cycle of $M$. mactroides.

Monthly oocyte size-frequency distribution histograms (Fig. 6) have proved to be a useful method for studying the gonad development of the yellow clam, as they have also been for several bivalves from previous studies (e.g. Donax hanleyanus: Penchaszadeh and Olivier 1975; Atrina seminuda: Soria et al. 2002; Tawera gayi: Morriconi et al. 2007). Unimodal histograms showed smaller size classes of oocytes $(>15 \mu \mathrm{m})$ in winter and spring, corresponding to a weak spawning event during June-August and a second stronger one during October-December of each year. The increase of oocyte diameters ( $15 \mu \mathrm{m}$ in July to $40 \mu \mathrm{m}$ in September) corresponds to gonad activity. The modal of oocyte sizes ranged between 15 and $45 \mu \mathrm{m}$ with lower values in winter (August 2005, July 2006) and spring 
(December-November 2005) due to gamete releases. The unimodality of the histograms (Fig. 6) explains the absence of successive periods of maturing oocytes.

Condition index, biomass, and recruitment

The CI is a useful tool to describe the reproductive cycle of marine bivalves with easily separable gonads (e.g. Mytilus edulis: Petersen et al. 2004; Hyotissa hyotis: DupratBertazzi and García-Domínguez 2005; Mercenaria mercenaria: Hofmann et al. 2006). This index generally indicates the gonadal mass changes throughout the year (Grant and Tyler 1983) with highest values when gonads are mature. The CI proved to indicate the gametogenic cycle even in bivalves with a gonad not easily separable from the foot such as Donax trunculus (Gaspar et al. 1999), D. serra (Laudien et al. 2001), and M. donacium (Riascos et al. 2008). However, for M. mactroides, the CI was not useful as it did not significantly correlate with the gametogenic cycle (cf. Fig. 5b, d). Although CI decreased in spring 2005 marking the main spawning period, in winter to Fall 2005, the values of CI were still low despite the gonads being mature and a high percentage of clams being ripe. A decrease in the $\mathrm{CI}$ as a result of spawning activity in 2006 was not identified. Thus, the CI is not useful to describe the spawning of the yellow clam. As a consequence of the prolonged spawning period of the population, all reproductive stages were present between May and December (Fig. 4). However, seasonal variation of the AFDM was positively correlated with SST as well as with the gametogenic cycle (Fig. 5a, c, e).

When assuming that the collected recruits originated from the studied adult population, the results indicate a meroplanktonic phase of approximately 3 months. Recruits appeared in the intertidal zone of Santa Teresita in summer-autumn of both years (from January to July 2005 and from February to May 2006), where the latter occurrence is apparently the result of the spawning event between November and December 2005 (Figs. 4, 5f, 6). After weak gamete release periods in July-August 2005 and June-July 2006 (Fig. 6), recruits were not present in the sampling area (Fig. 5f). However, the absence of recruits does not necessarily indicate a lack of spawning activity (Caddy and Defeo 2003) as environmental conditions, which strongly influence recruitment of marine invertebrates (e.g. hydrodynamic processes: Roughgarden et al. 1988; food limitation: Olson and Olson 1989; predators: Sale 1990), may not have been favourable for successful recruitment at the 'parent beach'. In contrast, four decades ago, Christiansen (1971) observed recruits during spring (November and December) as well as the recruitment event in summer (March). This may be due to changes in the population structure of $M$. mactroides during the last four decades; while Olivier and Penchaszadeh (1971) monitored three cohorts between 1968 and 1969, Herrmann (2009) detected only one cohort during 2005-2006.

In conclusion, only weak differences in the reproduction cycle and gonad development of $M$. mactroides between the present study and those of Christiansen (1971) were found. This could be due to the fact that recently just one cohort at one sandy beach was found (Herrmann 2009) and the beaches were dissimilar.

Acknowledgments This work was part of the doctor thesis of Marko Herrmann and subject of the diploma thesis (licenciatura) of José E. F. Alfaya, partly supported by 'Deutscher Akademischer Austauschdienst (DAAD)' and by the University of Bremen. The authors thank Sonia Cabrera, Maria Eugenia Segade Enrique, Juan Pablo Livore, my partner Sandra Noir, Francisco Villalba and Soledad Zabala for field assistance as well as the youngest helper Belén Alvela who measured water surface temperature off Santa Teresita each day. Additional thanks are also expressed to all Argentinean colleagues from the laboratory 19 at the Facultad de Ciencias Exactas y Naturales (UBA) and from the laboratory 80 at the Museo Argentino de Ciencias Naturales - 'Bernardino Rivadavia' (MACN).

\section{References}

Ansell AD (1961) Reproduction, growth and mortality of Venus striatula (da Costa) in Kames Bay, Millport. J Mar Biol Assoc UK 41:191-215

AxioVision (2008) Digital image processing software, AxioVision version 4.7.2. Carl Zeiss MicoImaging GmbH

Bastida RO, Roux A, Bremec C, Gerpe M, Sorensen M (1991) Estructura poblacional de la almeja amarilla (Mesodesma mactroides) durante el verano de 1989 en la Provincia de Buenos Aires, Argentina. Frente Marit 9A:83-92

Bastida RO, Ieno EN, Martin JP, Mabragaña E (1996) The yellow clam (Mesodesma mactroides): a case study of a coastal resource in risk from the South-West Atlantic Ocean. J Med Appl Malacol 8:165

Bergonci PEA, Thomé JW (2008) Vertical distribution, segregation by size and recruitment of the yellow clam Mesodesma mactroides Deshayes, 1854 (Mollusca, Bivalvia, Medodesmatidae) in exposed sandy beaches of the Rio Grande do Sul state, Brazil. Braz J Biol 68:631-637

Brazeiro A, Defeo O (1999) Effects of harvesting and density dependence on the demography of sandy beach populations: the yellow clam Mesodesma mactroides of Uruguay. Mar Ecol Prog Ser 182:127-135

Brey T, Rumohr H, Ankar S (1988) Energy content of macrobenthic invertebrates: general conversion factors from weight to energy. J Exp Mar Biol Ecol 117:271-278

Caddy JF, Defeo O (2003) Enhancing or restoring the productivity of natural populations of shellfish and other marine invertebrate resources. FAO Fisheries Technical Paper 448:168

Carreto JI, Lutz VA, Carignan MO, Cucchi Colleoni AD, de Marcos SG (1995) Hydrography and chlorophyll $a$ in a transect from the coast to the shelf-break in the Argentinian Sea. Cont Shelf Res 15:315-336

Christiansen HE (1971) Capitulo II: Reproduction. Estudio histologico del ciclo reproductivo. In: Olivier SR, Capezzani D, Carreto J, Christiansen H, Moreno V, de Moreno JA, Penchaszadeh PE (eds) Estructura de la Comunidad, Dinámica de la Población y Biología de la Almeja Amarilla (Mesodesma mactroides) en Mar 
Azul. Proyecto de desarrollo pesquero: publicación/Gobierno Argentino y programa de las Naciones Unidas para el desarrollo (FAO, Agencia Ejecutiva) 27:36-48

Coscarón S (1959) La almeja amarilla (Mesodesma (T.) mactroides Deshayes) de la costa de la Provincia de Buenos Aires. Dir Agrop Publ Tec 1:66

Darriba S, San Juan F, Guerra A (2004) Reproductive cycle of the razor clam Ensis arcuatus (Jeffreys, 1865) in northwest Spain and its relation to environmental conditions. J Exp Mar Biol Ecol 311:101-115

Darriba S, San Juan F, Guerra A (2005) Gametogenic cycle of Ensis siliqua (Linnaeus, 1758) in the Ría de Corcubión, northwestern Spain. J Moll Stud 71:47-51

Defeo O (1989) Development and management of artisanal fishery for yellow clam Mesodesma mactroides in Uruguay. Fishbyte 7:2125

Defeo O, Layerle C, Masello A (1986) Spatial and temporal structure of the yellow clam Mesodesma mactroides (Deshayes 1854) in Uruguay. Medio Ambiente 8:48-57

Defeo O, Rey M, Cascudo J (1988) Estimaciones de stock del recurso almeja amarilla (Mesodesma mactroides) en base al análisis de cohortes (Pope, 1972). Publ Com Téc Mix Fr Mar 4:41-54

Defeo O, Seijo JC, Euan J, Liceaga M (1991) Dinámica espacial del esfuerzo pesquero en una pesquería artesanal de la costa Atlántica Uruguaya. Invest Pesq (Chile) 36:17-25

Defeo O, Ortiz E, Castilla JC (1992) Growth, mortality and recruitment of the yellow clam Mesodesma mactroides on Uruguayan beaches. Mar Biol 114:429-437

Delgado E, Defeo O (2007) Tisular and population level responses to habitat harshness in sandy beaches: the reproductive strategy of Donax hanleyanus. Mar Biol 152:919-927

Deshayes MGP (1855) Descriptions of new shells from the collection of Hugh Cuming. Esq Proc Zool Soc Lond 22:317-371

de Villiers G (1975) Reproduction of the sand mussel Donax serra Roding. S Afr Sea Fish Branch Invest Rep 103:1-33

Duprat-Bertazzi G, García-Domínguez F (2005) Reproductive cycle of the rock oyster Hyotissa hyotis (Linné, 1758) (Griphaeidae) at the la Ballena Island, Gulf of California, México. J Shellfish Res 24:987-993

Filun Villablanca LO (1992) Ecologia reproductiva de Mesodesma donacium (Lamarck, 1818) (Bivalvia: Mesodesmatidae), en la playa de Mehuin, Provinvia de Valdivia. Dissertation, Universidad Austral de Chile, Facultad de Ciencias, Escuela de Graduados, $\mathrm{p} 73$

Fiori SM, Cazzaniga NJ (1999) Mass mortality of the yellow clam, Mesodesma mactroides (Bivalvia: Mactracea) in Monte Hermoso beach, Argentina. Biol Conserv 89:305-309

Fiori SM, Cazzaniga NJ (2002) Individual biomass and allometry of Mesodesma mactroides from the Southern coast of Buenos Aires, Argentina (Bivalvia, Mactracea). In: Proceedings of V CLAMA. pp 227-228

Fiori SM, Defeo O (2006) Biogeographic patterns in life-history traits of the yellow clam, Mesodesma mactroides, in sandy beaches of South America. J Coast Res 22:172-180

Fiori SM, Morsán EM (2004) Age and individual growth of Mesodesma mactroides (Bivalvia) in the southernmost range of its distribution. J Mar Sci 61:1253-1259

Fiori SM, Cazzaniga NJ, Estebenet A (2004) Winter distribution, density and size of Mesodesma mactroides (Bivalvia, Mactracea) in Monte Hermoso beach (Argentina). Braz J Ocean 52:1-9

Gaspar MB, Ferreira R, Monteiro CC (1999) Growth and reproductive cycle of Donax trunculus L., (Mollusca: Bivalvia) off Faro, southern Portugal. Fish Res 41:309-316

Giese AC (1974) Introduction: general principles. In: Giese AC, Pearse JS (eds) Reproduction of marine invertebrates. Academic, New York, pp 1-49
Gil GM, Thomé JW (2000) Interações biológicas entre moluscos na praia de Arroio Teixeira, RS. Rev Bras de Zoociências Juiz de Fora 2:41-50

Grant A, Tyler PA (1983) The analysis of data in studies of invertebrate reproduction. I. Introduction and statistical analysis of gonad indices and maturity indices. Int J Invertebr Reprod 6:259-269

Herrmann M (2009) Population dynamics of the surf clams Donax hanleyanus and Mesodesma mactroides from open-Atlantic beaches off Argentina. Rep Pol Mar Res 585:235

Herrmann M, Alfaya JEF, Penchaszadeh PE, Laudien J (2008) Sea surface temperature at station Santa Teresita and data from Mesodesma mactroides (Bivalvia: Mesodesmatidae) from northern Argentina, dataset. PANGAEA-Publishing Network for Geoscientific \& Environmental Data. http://doi.pangaea.de/10. 1594/PANGAEA.704576

Hofmann EE, Klinck JM, Kraeuter JN, Powell EN, Grizzle RE, Buckner SC, Bricelj VM (2006) A population dynamics model of the hard clam, Mercenaria mercenaria: development of the age- and length-frequency structure of the population. J Shellfish Res 25:417-444

Kraeuter JN, Castagna M (2001) Biology of the hard clam. Developments in aquaculture and fisheries science, vol 31. Elsevier, Amsterdam, p 751

Laudien J, Brey T, Arntz WE (2001) Reproduction and recruitment patterns of the surf clam Donax serra (Bivalvia, Donacidae) on two Namibian sandy beaches. S Afr J Mar Sci 23:53-60

Lima M, Brazeiro A, Defeo O (2000) Population dynamics of the yellow clam Mesodesma mactroides: recruitment variability, density-dependence and stochastic processes. J Exp Mar Biol Ecol 207:97-108

McLachlan A (1980) The definition of sandy beaches in relation to exposure: a simple rating system. S Afr J Mar Sci 76:137-138

Morriconi E, Lomovasky BJ, Calvo J (2007) Reproductive cycle and energy content of Tawera gayi (Hupé 1854) (Bivalvia: Veneridae) at the southernmost limit of their distribution range. J Shellfish Res 26:81-88

Narchi W (1981) Aspects of the adaptive morphology of Mesodesma mactroides (Bivalvia: Mesodesmatidae). Malacologia 21:95-110

Odebrecht C, Rörig L, Gracia VT, Abreu PC (1995) Shellfish mortality and red tide event in southern Brazil. In: Lassus P (ed) Harmful marine algal blooms. Springer, New York, pp 213-218

Olivier SR, Penchaszadeh PE (1971) Capitulo I: Ecología General. In: Olivier SR, Capezzani D, Carreto J, Christiansen H, Moreno V, de Moreno JA, Penchaszadeh PE (eds) Estructura de la Comunidad, Dinámica de la Población y Biología de la Almeja Amarilla (Mesodesma mactroides) en Mar Azul. Proyecto de desarrollo pesquero: publicación / Gobierno Argentino y programa de las Naciones Unidas para el desarrollo (FAO, Agencia Ejecutiva) 27:13-35

Olivier SR, Capezzani D, Carreto J, Christiansen H, Moreno V, de Moreno JA, Penchaszadeh PE (1971) Estructura de la Comunidad, Dinámica de la Población y Biología de la Almeja Amarilla (Mesodesma mactroides) en Mar Azul. Proy Des Presq FAO 27:1-90

Olson RR, Olson MH (1989) Food limitation of planktotrophic marine invertebrate larvae: does it control recruitment success? Annu Rev Ecol Syst 20:225-247

Parodiz JJ (1942) Transgressiones oceánicas y fauna del Mar Epicontinental Argentino. Rev Geográf Amer 18:203-211

Penchaszadeh PE, Olivier SR (1975) Ecología de una población de 'berberecho' (Donax hanleyanus) en Villa Gesell, Argentina. Malacologia 15:133-146

Penchaszadeh PE, Paredes C, Salaya JJ (2000) Reproductive cycle of the south American scallop Amusium laurenti (Gmelin, 1791) (Bivalvia, Pectinidae). Aqua Int 8:227-235 
Peredo S, Parada E, Valdebenito I (1986) Gametogenesis and reproductive cycle of the surf clam Mesodesma donacium (Lamarck, 1818) (Bivalvia: Mesodesmatidae) at Queule Beach, southern Chile. Veliger 30:55-68

Petersen JK, Bougrier S, Smaal AC, Garen P, Robert S, Larsen JEN, Brummelhuis E (2004) Intercalibration of mussel Mytilus edulis clearance rate measurements. Mar Ecol Prog Ser 267:187-194

Reeve LA (1854) Monograph of the genus Donax. Conchologia Iconica $8: 1-9$

Riascos JM, Heilmayer O, Oliva M, Laudien J, Arntz WE (2008) Infestation of the surf clam Mesodesma donacium by the spionid polychaete Polydora bioccipitalis. J Sea Res 59:217-227

Rios EC (1994) Seashells of Brazil, 2nd edn. Editora da Fundação Universidade de Rio Grande, p 481

Romeis B (1989) Mikroskopische Technik, 17th edn. Urban \& Schwarzenberg, Münschen, p 697

Roughgarden J, Gaines S, Possingham H (1988) Recruitment dynamics in complex life cycles. Science 241:1460-1466

Sale PF (1990) Recruitment of marine species: is the bandwagon rolling in the right direction? Trends Ecol Evol 5:25-27

Sastry AN (1968) The relationships among food, temperature, and gonad development of the bay scallops Aequipecten irradians Lamarck. Physiol Zool 41:44-53

Sastry AN (1970) Reproductive physiological variation in latitudinally separated populations of the bay scallop Aequipecten irradians Lamarck. Biol Bull 138:56-65
Sastry AN (1979) Pelecypoda (excluding Ostreidae). In: Giese AC, Pearse JS (eds) Reproduction of marine invertebrates. Academic, New York, pp 113-292

Seed R (1976) Ecology. In: Bayne BL (ed) Marine mussels: their ecology and physiology. Cambridge University Press, Cambridge, pp 13-65

Short AD, Wright LD (1983) Physical variability of sandy beaches. In: McLachlan A, Erasmus T (eds) Sandy Beaches as Ecosystems. Junk, The Hague, pp 133-144

Soria RG, Pascual MS, Fernández Cartens V (2002) Reproductive cycle of the cholga paleta, Atrina seminuda, Lamarck, 1819 (Bivalvia: Pinnidae) from the Northwest Patagonia, Argentina. J Shellfish Res 21:479-488

SPSS (2008) Statistical package for the social sciences, version 17.0. SPSS inc, Chicago

Stuardo BJ (1964) Distribución de los moluscos marinos litorales en Latinoamérica. Bol Inst Biol Mar Mar del Plata 7:79-91

Thompson GA, Sánchez de Bock MF (2007) Mortandad masiva de Mesodesma mactroides (Bivalvia: Mactracea) en el partido de la costa, Buenos Aires, Argentina, en Septiembre 2004. Atlântica Rio Grande 29:115-119

Zar JH (1999) Biostatistical analysis, 4th edn. Prentice-Hall, Upper Saddle River, p 663 